\title{
Typification of the genus Zizyphoides Seward et Conway (Magnoliophyta, Trochodendraceae)
}

\author{
ANASTASIA A. ZOLINA ${ }^{1 *}$, STEVEN R. MANCHESTER ${ }^{2}$ and LINA B. GOLOVNEVA ${ }^{1}$ \\ ${ }^{1}$ Komarov Botanical Institute, Russian Academy of Science, St. Petersburg, Russia; \\ e-mail: azolina@binran.ru \\ ${ }^{2}$ Florida Museum of Natural History, Gainesville, USA
}

Received 28 May 2021; accepted for publication 1 December 2021

\begin{abstract}
Type material of Paliurus colombii Heer, Populus arctica Heer, Hakea arctica Heer, and Hedera macclurii Heer from the Atanikerdluk locality (Paleocene, Greenland) was restudied based on the original collection, stored in the National Museum of Ireland, Dublin. All these species were joined under the name Zizyphoides colombii (Heer) Seward et Conway, type species of the genus Zizyphoides Seward et Conway. A lectotype of Zizyphoides colombii is designated and the diagnosis of this species is emended. An emended diagnosis of the genus Zizyphoides is also presented.
\end{abstract}

KEYWORDS: Zizyphoides, Trochodendroides, Atanikerdluk, Greenland, Trochodendraceae, Paleocene

\section{INTRODUCTION}

The genus Zizyphoides Seward et Conway was established for leaves similar in morphology and venation with leaves of modern genera Zizyphus and Paliurus (Seward and Conway, 1935) and assigned by its authors to family Rhamnaceae. The type species of this genus is Zizyphoides colombii (Heer) Seward et Conway, based on Paliurus colombii Heer, which was described from the Paleocene of West Greenland (Heer, 1868). Seward and Conway referred only one incomplete specimen from the locality Kagdlunguak, West Greenland to the new combination Zizyphoides colombii (historical and modern geographic site names synonyms are given in Table 1 in chapter "Material and methods"). They did not designate a type for the new genus and did not publish a formal morphological diagnosis or description. But since the genus Zizyphoides included only one species at that time, the diagnosis of Paliurus colombii is also the diagnosis of the genus Zizyphoides.

\footnotetext{
Corresponding author
}

The suggestion of Seward and Conway (1935) was not accepted by the majority of paleobotanists, who preferred to use the name of the modern genus Zizyphus for elongated fossil leaves with entire or crenate margin and actinodromous venation from the Upper Cretaceous and Paleogene (Hollick, 1936; Budantsev, 1968; Herman and Lebedev, 1991; Philippova and Abramova, 1993; Philippova, 2010). Some authors later transferred several species of fossil Zizyphus from the Upper Cretaceous of Russia to the genus Zizyphoides (Budatsev, 1983; Herman, 2011). However, all these combinations are invalid, because their basionyms were not indicated.

A revised concept of the genus Zizyphoides was proposed by Crane, Manchester and Dilcher (Crane et al., 1991; Manchester et al., 1991). Study of the reproductive structures belonging to the extinct genus Nordenskioldia Heer (more correctly Nordenskioeldia, being named in recognition of the collector, Nordenskiöld), showed that these fruits are associated with 
certain type of leaves with actinodromous venation and entire or crenate margin. The morphology of these leaves matched that of the genus Zizyphoides therefore they were referred to this genus. Crane et al. (1991) considered all Paleocene leaves of Zizyphoides as conspecific. The earliest epithet for this species is Zizyphoides flabella (Newberry) Crane, Manchester et Dilcher, based on Populus flabella Newberry from the Paleocene to Eocene Puget Group of Chuckanut near Bellingham Bay, Washington, USA.

The latter concept has been widely accepted among paleobotanists. Later two additional species were described: Z. auriculata (Heer) Manchester, Crane et Dilcher from the Miocene of North America and Japan (Manchester et al., 1991; Tanai, 1961) and Zizyphoides ezoensis (Tanai) Manchester, Chen, Geng et Tao from the Eocene of China and Japan (Manchester et al., 2005).

However, the type species of the genus Zizyphoides (Z. colombii) remained beyond the scope of consideration. This material has not been revised since Heer's time. The concept of this species is based only on the drawings in Heer's monograph. It was not typified and the identity of $Z$. colombii and $Z$. flabella was not reevaluated based on their type specimens.

Besides that, $Z$. flabella was considered as conspecific with some of the specimens subsequently assigned to another species - Populus arctica Heer (Crane et al., 1991), which was also described by Heer (1868) from the Paleocene of West Greenland. However, the latter species was already proposed by Berry (1926) as basionym for the combination Trochodendroides arctica (Heer) Berry. Many authors treated T. arctica as the most typical and widely distributed species of the genus Trochodendroides (Baikovskaya, 1956; Kryshtofovich and Baikovskaya, 1966; Budantsev, 1983; Herman, 2013). The leaves of Zizyphoides and Trochodendroides are very similar in their venation patterns. They often occur together and both genera are among the most common components of latest Cretaceous and early Tertiary floras. But leaves of Trochodendroides (sensu Crane, 1984) are usually associated with $\mathrm{Cer}$ cidiphyllum-like fruits (Crane, 1984; Crane and Stockey, 1985, 1986), which now are treated as belonging to the genus Jenkinsella Reid and Chandler (Golovneva and Alekseev, 2017). However, the type material of Populus arctica was also never revised.

The aims of this paper are to restudy the type material of Paliurus colombii and Populus arctica in detail, to choose a lectotype for Paliurus colombii and to provide an emended diagnosis for the genus Zizyphoides and its type species $Z$. colombii.

\section{MATERIAL AND METHODS}

Type material of Paliurus colombii and Populus arctica was studied in the National Museum of Ireland in Dublin. These specimens are derived from the Colomb collection which was transferred to the Museum from the Royal Dublin Society in about 1889.

The plant fossils were collected on the south coast of the Nuussuaq peninsula, West Greenland, during the Arctic Expedition of 1854 (Fig. 1). Lieutenant Philip Howard Colomb served as mate of HMS "Phoenix". This ship supplied the search for the Franklin

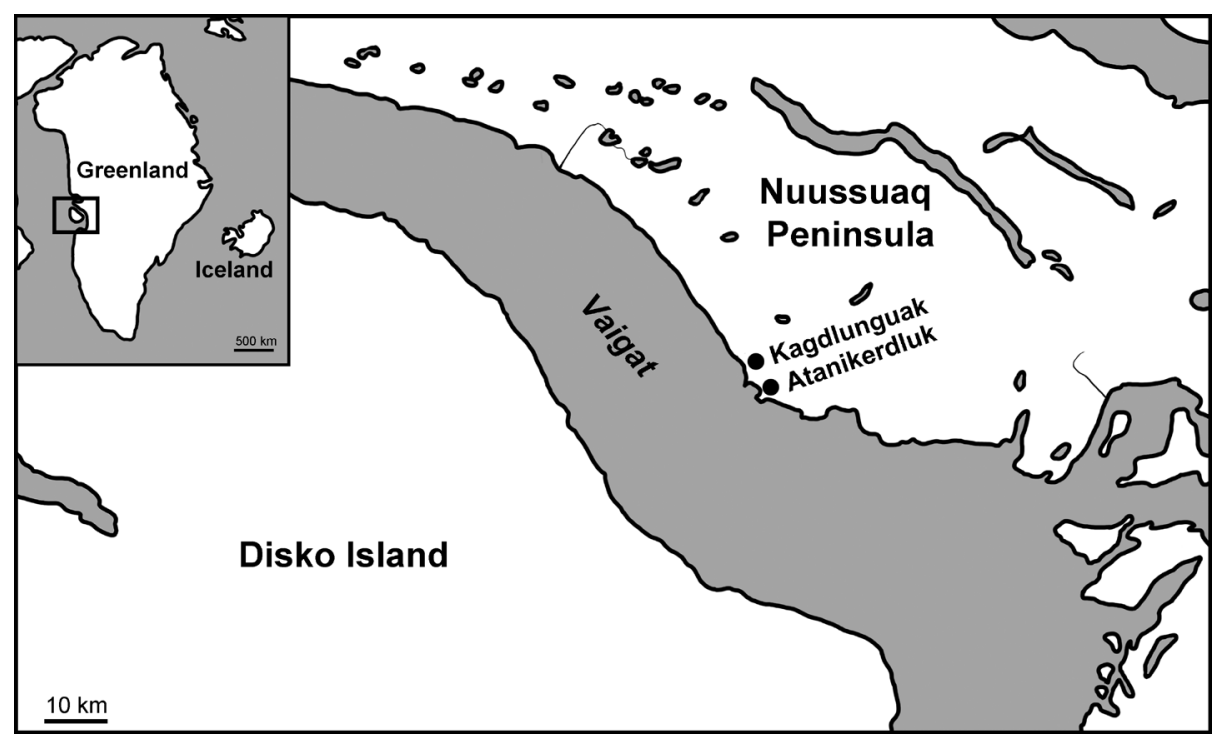

Fig. 1. Localities of Zizyphoides colombii (Heer) Seward et Conway in West Greenland 
expedition overseen by Sir Edward Belcher. Captain of the "Phoenix", Sir Edward Augustus Inglefield, brought home the ship's crew of HMS "Investigator", which had become trapped in the ice.

Captain Inglefield and lieutenant Colomb visited the locality Atanikerdluk, Greenland on July 7, 1854. The plant fossil collection site is indicated in the drawing of Colomb, published by Heer (1868: p. 9). Leaves of Paliurus colombii with remains of other species were found on the slope of a cone-shaped mountain at an altitude of about 1,000 feet above the layer with fossil wood and below several thin coal seams. On return home, Inglefield transferred his part of the collection to the Geological Survey in London. Now these fossils are stored in the Natural History Museum, London. The specimens collected by Colomb were donated to the Royal Dublin Society on November 24, 1854.

The geology of the Atanikerdluk area was investigated by A.E. Nordenskiöld (1871). In this area Cretaceous and Tertiary deposits are exposed. The Tertiary sediments were assigned by Nordenskiöld to the Upper Atanikerdluk Formation. Later B.E. Koch (1959) divided plant-bearing deposits into the Quikavsak and the Naujat members. According to Koch, the Quikavsak member consists of fluviatile deposits of conglomerates, sandstones and shales. The Naujat member mostly consists of black shales with a few brown tuff bands near the bottom.

The plant fossils from the Colomb collection are leaf impressions preserved in sideritic shales. The sediments vary from fine-grained sandstone to siltstone. Such siderite-impregnated shales with numerous plant fossils are characteristic for the Quikavsak member (Koch, 1959), and we believe that type specimens of Paliurus colombii and Populus arctica came from these layers. Locality Kagdlunguak, from which Seward and Conway (1935) described one leaf of Zizyphoides colombii, should be assigned, according to Koch (1963), to the Naujat member.

Now the Quikavsak member of the Upper Atanikerdluk Formation is considered as a separate formation (Dam et al., 2009). The Quikavsak Formation is $70-180 \mathrm{~m}$ thick. Its age is determined as early Paleocene (Danian) based on the stratigraphic position between the Kangilia Formation, of Danian age, and the overlying Eqalulik Formation of Danian to
Selandian age (Dam et al., 2009). The Naujat member is now part of the new Atanikerluk Formation (early to mid-Paleocene in age).

Plants from the Colomb collection were studied by Heer (1868), who described four specimens (Fig. 2a-d) under the name Paliurus colombii. All of them survived in the collection of the National Museum of Ireland (NMING). Three specimens are almost whole elliptic leaves. Among them one leaf is represented by part and counterpart (Pl. 1, figs 2, 3). The fourth specimen is a poorly preserved lower half of a widely elliptic leaf (Pl. 1, fig. 5). This leaf is slightly larger than the other Paliurus colombii syntypes and its margin is not preserved. It is more similar to leaves attributed to Populus arctica in its lamina shape. After examination of this material, we designate a specimen (NMING F19201/2), which most fully reflects the characters of this species, as lectotype of Paliurus colombii. This specimen was figured by Heer (1868) in Taf. V, Fig. 8 (Fig. 2e), and is refigured in this paper in $\mathrm{Pl}$. 1, figs 4, 6, 7 .

Description of Populus arctica is based on material from several samplings, obtained by different collectors (Olrik, M'Clintock, Colomb, Lyall, Torell) in different years (Heer, 1868). We attribute only specimens from the Colomb collection to the type material of Populus arctica. Altogether 30 specimens were described under the name Populus arctica in the Colomb collection catalogue, compiled by Nigel Monaghan from NMING (Figs $3,4)$. Among them 23 were figured by Heer (1868) and 7 remained unfigured. Specimens, figured in Taf. V, Fig. 1b and Fig. 14, are not leaves but probably bark and fruits (Fig. 3). Several specimens have bad preservation and do not show any characteristic features, or strongly differ from the other leaves in venation and margin details (Heer, 1868: Taf. V, Figs 10, 13 and three nonfigured leaves). After excluding questionable specimens, we considered only 24 leaves from type sampling to characterize $P$. arctica (list in the chapter "Material" in the systematic part). The best specimens are shown photographically and in drawings in this paper ( $\mathrm{Pl}$. 1, figs $8-11$; Pl. 2; Pl. 3, figs 7-9; Fig. 5e-h, j). The lectotype of $P$. arctica was chosen by Iljinskaja (1972) based only on Heer's illustration (Heer, 1868: Taf. V, Fig. 8; this paper, Fig. 5I). Unfortunately, this leaf is missing in the Colomb collection and its location and place of sampling are not known.
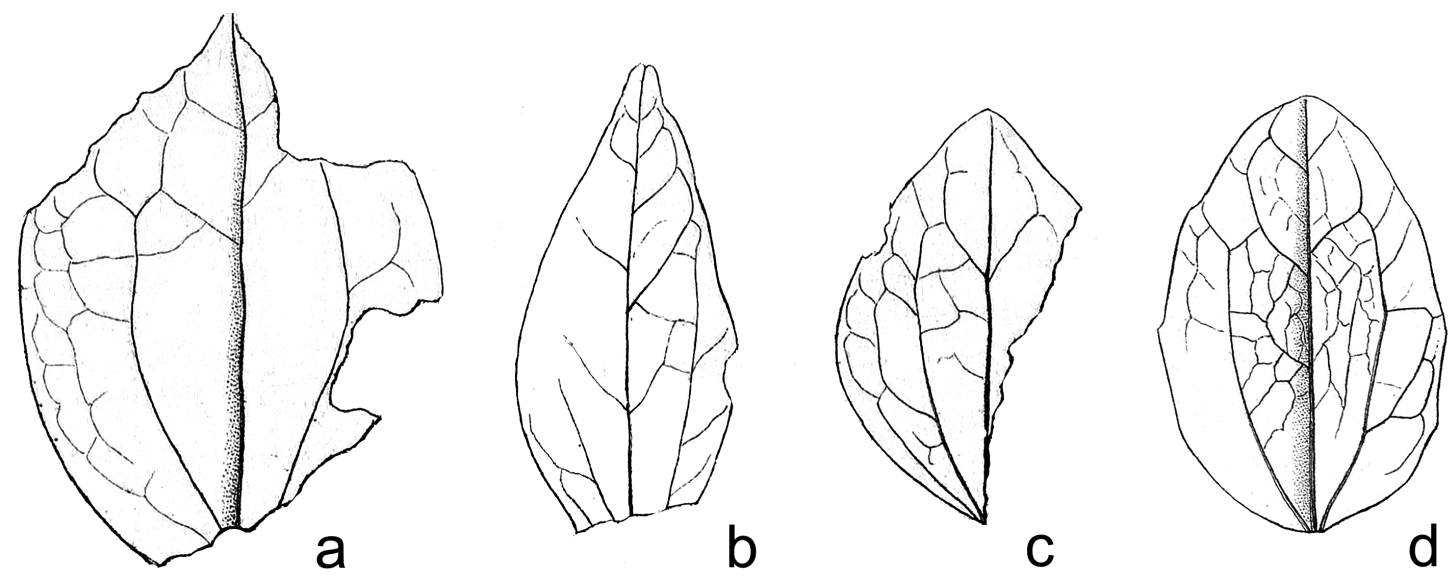

Fig. 2. Type material of Paliurus colombii Heer figured by Heer (1868): a. Taf. XIX, Fig. 4; b. Taf. XIX, Fig. 2; c. Taf. XIX, Fig. 3; d. Taf. XVII, Fig. 2d 
Table 1. Locality and geographic site names' synonyms

\begin{tabular}{l|l}
\hline \hline $\begin{array}{c}\text { Modern Greenlandic orthography } \\
\text { (Dam et al., 2009) }\end{array}$ & \multicolumn{1}{c}{$\begin{array}{c}\text { Geographic names' synonyms } \\
\text { in old literature }\end{array}$} \\
\hline Atanikerluk & $\begin{array}{l}\text { Atanekerdluk (Heer, 1868), } \\
\text { Atanikerdluk (Seward and Conway, 1935; Koch, 1963) }\end{array}$ \\
\hline Qallunguaq & $\begin{array}{l}\text { Kardlunguak (Heer, 1868), } \\
\text { Kagdlunguak (Seward and Conway, 1935) }\end{array}$ \\
\hline Nuussuaq Peninsula & $\begin{array}{l}\text { Noursoak (Heer, 1868) } \\
\text { Nûgssuaq (Koch, 1963) }\end{array}$ \\
\hline Vaigat Straitt & Waigatt (Heer, 1868) \\
\hline
\end{tabular}

In addition to Paliurus colombii and Populus arctica, the Colomb collection contains several more specimens indistinguishable from leaves of these two species. These are leaves, described under the names Hedera macclurii Heer, Hakea? arctica Heer and some of those called Populus zaddachi Heer. The first of these is represented by four specimens, and the second one is represented by two specimens. These two names are considered synonymous with Paliurus colombii and Populus arctica. The species Populus zaddachi was first described from the Tertiary European floras (Heer, 1859). The Greenlandic material is generally different from the European, and Heer (1868) described quite different leaves under this name from Atanikerdluk. Formal systematic revision of this species is beyond the scope of this paper. Only one specimen (Heer, 1868: Taf. VI, Fig. 3) bears a resemblance to the leaves of Paliurus colombii (Pl. 3, figs 5, 6). All these specimens are also used to characterize the species Zizyphoides colombii.

Unfortunately, the infructescences of Nordenskioeldia, that usually co-occur with leaves of Zizyphoides in other localities, are not present in the National Museum of Ireland collection.

All material is preserved only as impressions. Leaf architectural terminology follows that of "Manual of Leaf Architecture" (Ellis et al., 2009). Photographs of the specimens were made using a Sony RX100II camera with low angle illumination.

The Geographic site names used in this paper are in modern Greenlandic orthography (after Dam et al., 2009). However, older spelling was used for locality names (Table 1), which were given by Seward and Conway (1935), as they are widely used in paleobotany.

\section{SYSTEMATIC DESCRIPTIONS}

\section{Family: TROCHODENDRACEAE}

Genus: Zizyphoides

Seward et Conway, emend.

\section{Type species: Zizyphoides colombii (Heer) Seward et Conway}

Species composition:

1) Z. flabella (Newberry) Crane, Manchester et Dilcher, Paleocene, North America.
2) Z. auriculata (Heer) Manchester, Crane et Dilcher, Miocene, North America and Japan.

3) Z. ezoensis (Tanai) Manchester, Chen, Geng et Tao, Eocene, China and Japan.

Diagnosis emended. Leaves simple, with long petiole, narrowly to broadly elliptical, ovate, obovate, orbicular, deltoid or transversely elliptical. Apex obtuse, rounded or acute, frequently with attenuate obtuse tip with a slight retuse glandular incision. Base cuneate, rounded and slightly cordate. Margin often entire or undulate, but also crenate, scalloped, or irregularly dentate. Teeth irregular in size and shape, usually distantly spaced, broadly triangular with obtuse apices, or scalloped with rounded or obtuse, truncate apices; with apical glands or eglandular. Sinuses triangular, broadly triangular, or rounded. Eglandular crenations supplied by looping marginal veins and lacking a clearly defined single central vein. Glandular crenations with a distinct central vein running to the tip and a pair of lateral accessory veins that converge toward the base of the gland.

Venation actinodromous, with 3-5 pairs of thin primary veins. Midvein strait or undulating, running to the leaf apex, producing 2-5 alternately arranged secondary veins in the upper one-third of the lamina. Inner lateral veins thin, curving, running to the apex and connecting with lower secondary veins extending from the midrib. Secondary veins arising from the midvein and inner lateral primaries form brochidodromous loops in the upper part of the lamina. First strong secondary veins arising from the inner lateral primaries usually in the basal one-third to one-half of the leaf lamina. Outer lateral primary veins (if present) thinner than inner primaries and diverging at a wider angle from the midvein. Their basiscopic branches form well-developed brochidodromous loops in the lower half of the lamina. Tertiary veins between the primaries and their main branches percurrent, forming irregular arched 
GRÖN LAND

V

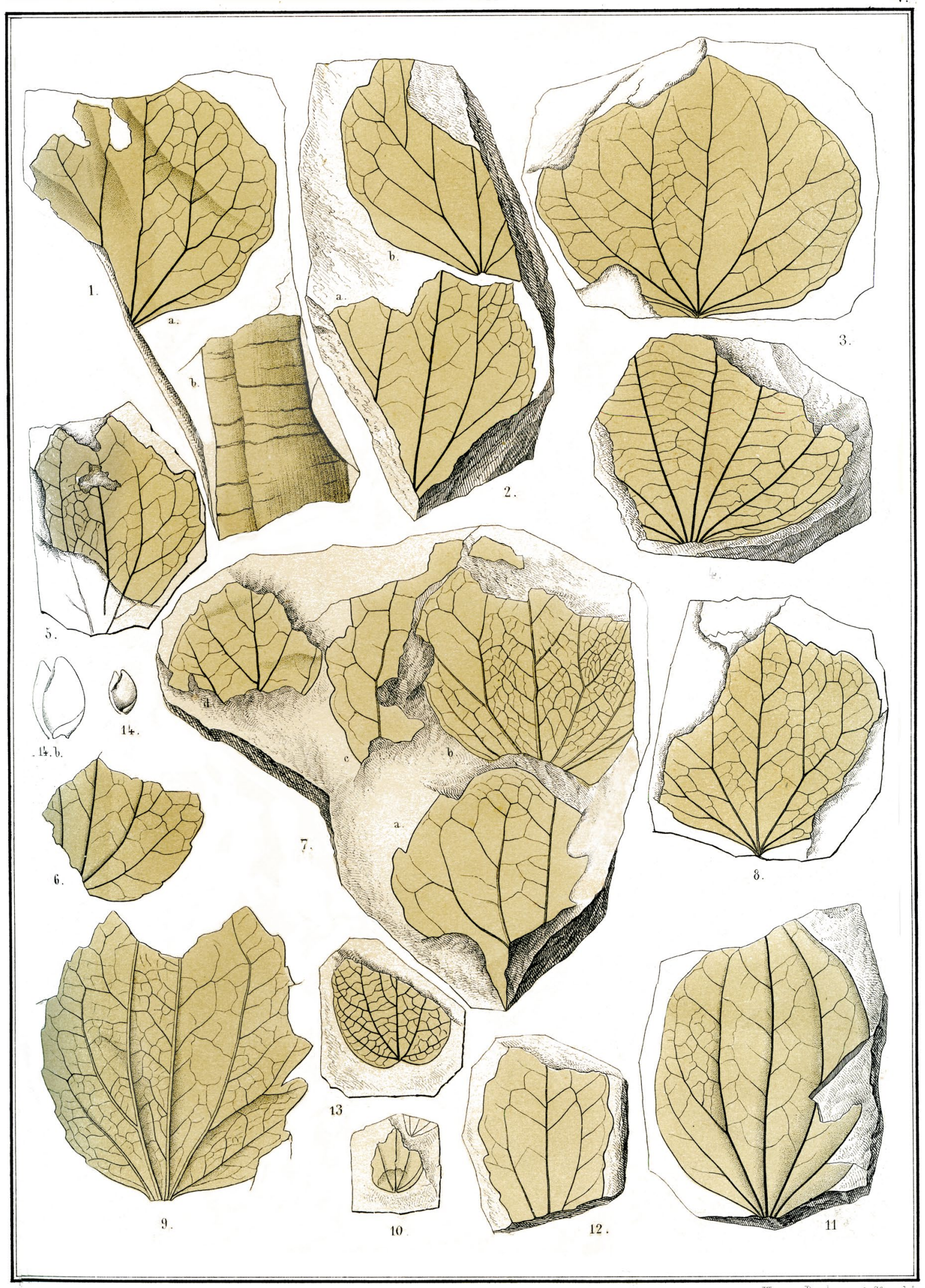

Populus arctica.

Fig. 3. Reproduction of the original illustration from Heer (1868, Taf. V) depicting leaves that he named Populus arctica 

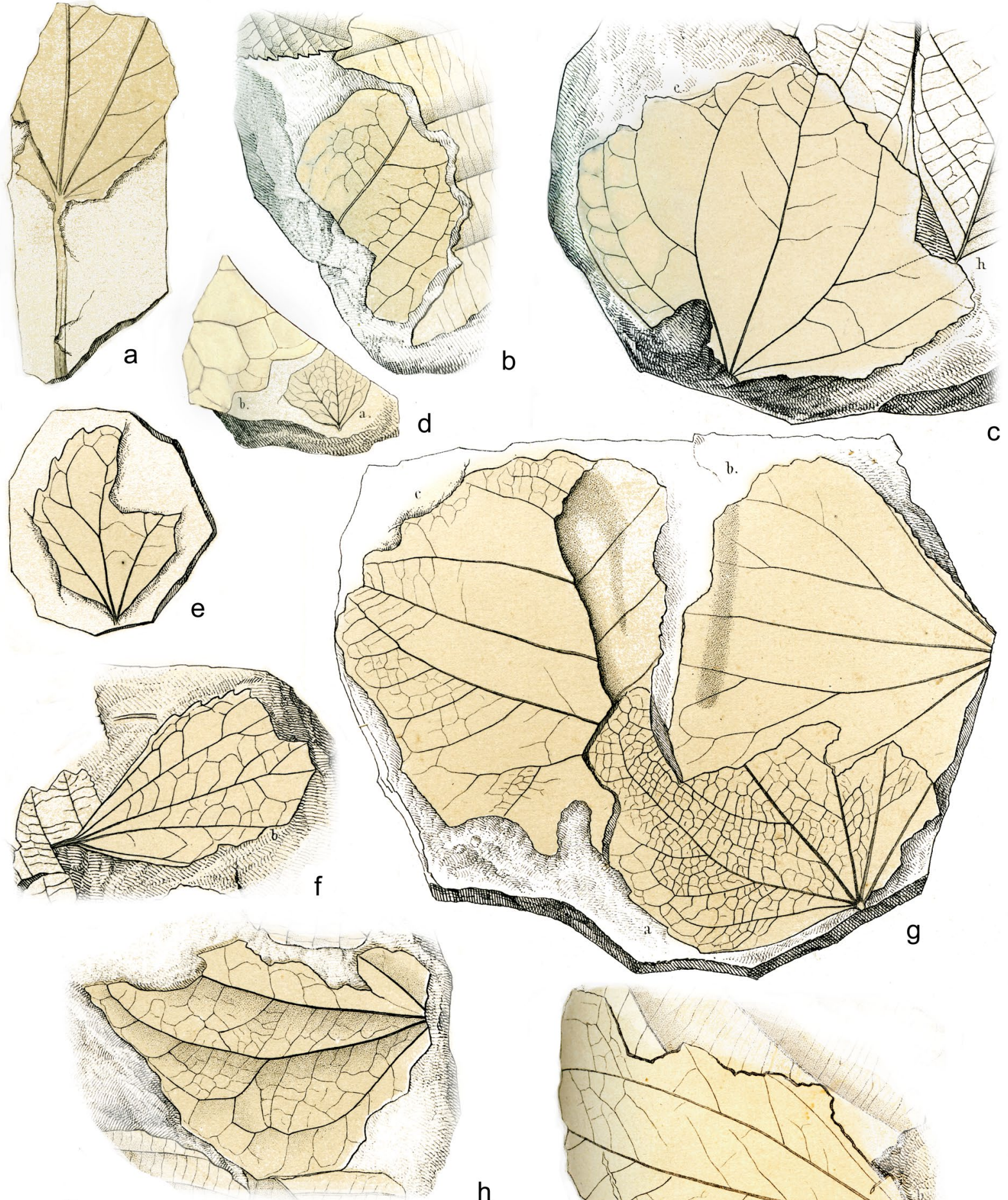

h

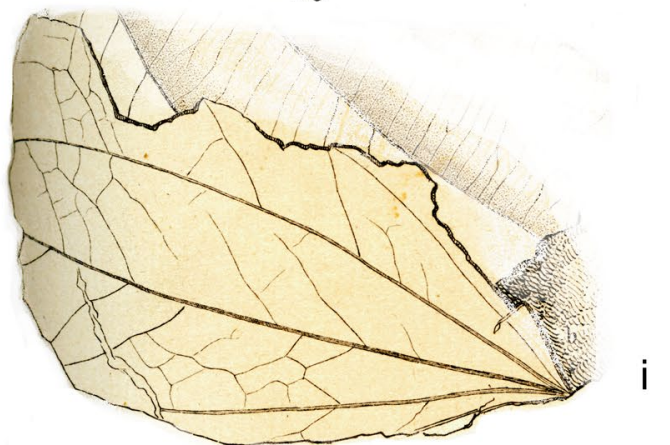

Fig. 4. Reproduction of the original illustration from Heer (1868) depicting leaves he named treated as Populus arctica. a. Orig. Taf. IV, Fig. 7; b. Orig. Taf. VIII, Fig. 6; c. Orig. Taf. XVII, Fig. 5c; d. Orig. Taf. IV, Fig. 6a; e. Orig. Taf. VI, Fig. 7; f. Orig. Taf. XVII, Fig. 5b; g. Orig. Taf. VI, Fig. 6; h. Orig. Taf. VIII, Fig. 5; i. Orig. Taf. XIX, Fig. 7b

connections. Looping secondary veins producing tertiaries that form additional abmedial loops toward the margin. Quaternary veins arising perpendicular to the lower order venation and typically forming an orthogonal network. Quinternary veins also arising orthogonally and delimiting polygonal, frequently rectangular areoles, with strait to curved freely ending veinlets. Veinlets with up to three orders of branching, sometimes rejoining veins of lower order resulting in still finer areoles apparently with no freely ending veinlets. 


\section{Zizyphoides colombii (Heer)}

Seward et Conway

Pls 1-3; Fig. 5

Selected Greenland synonymy (Heer, 1868, Colomb collection, and Seward and Conway, 1935).

1866 Paliurus colombii Heer, S. 279; Heer, 1868, S. 122, Taf. XVII, Fig. 2d, Taf. XIX, Figs 2-4;

1868 Populus arctica Heer, pro parte, S. 100; Taf. IV, Fig. 7; Taf. V, Figs 1a, 2-9, 11, 12; Taf. VIII, Figs 5, 6; Taf. XVII, Figs 5b, c.

1868 Populus zaddachii auct. non Heer (1859), Heer, pro parte, Taf. VI, Fig. 3.

1868 Hedera macclurii Heer, Taf. XVII, Figs 1a, 2c, 3, $4,5$.

1868 Hakea? arctica Heer, Taf. XV, Figs 5, 6.

1935 Zizyphoides colombii (Heer) Seward et Conway, p. 23.

Lect oty pe (designated here). NMING, Dublin, F19201/2.

Type locality. Atanikerdluk, Greenland.

Type stratum. Quikavsak Formation.

Ag e. Early Paleocene.

Material. National Museum of Ireland, Dublin, Colomb collection: described under name Paliurus colombii Heer - F19172A/1; F19172B/1; F19177/4; F19201/2; F19253/2; described under name Populus arctica Heer - F19172B/2; F19195; F19196; F19197; F19198A/1; F19198A/2; F19198B/1; F19201/1; F19202; F19212/2; F19215/1; F19215/3; F19215/4; F19215/5; F19215/6; F19237/2; F19261/1; F19283/3; F19290/3; F19291/5; F19291/6; F19291/21; F19291/23; F19293/2; described under name Hedera macclurii F19174; F19201/3; F19280/1; F19291/20; described under name Populus zaddachii Heer - F19263; described under name Hakea? arctica Heer - F19294A/3; F19294B/2; F19294C/2.

Diagnosis emended. Leaves narrowly to broadly elliptical, ovate, orbicular or transversely elliptical; base cuneate, rounded or slightly cordate; apex obtuse, rounded, or acute; margin entire, undulate, crenate or irregularly dentate. Teeth distantly spaced, 1-3 $\mathrm{mm}$ in length, broadly triangular with obtuse or rounded apices, usually eglandular, with distinct central vein.

Description. Leaves are simple, petiolate. Lamina is subcoriaceous, highly variable in shape, narrowly to broadly elliptical, ovate, orbicular or transversally elliptical, $3-6.5 \mathrm{~cm}$ in length and $1.3-7 \mathrm{~cm}$ in width. Apex is obtuse, rounded or acute, commonly with attenuate obtuse tip. Base is cuneate, rounded and frequently slightly cordate. The smaller and narrower leaves are usually entire-margined. Larger leaves have wavy, crenate or irregularly dentate margin. Teeth are distantly spaced, 1-3 $\mathrm{mm}$ in length, broadly triangular with obtuse or rounded apices, usually eglandular, with distinct central vein. Wavy margin is supplied by looping marginal veins.

Venation is actinodromous, with midvein and 1-2 pairs of lateral primary veins. The midvein runs directly to the leaf apex. Inner lateral veins shorter and less pronounced than midvein, usually curving inward apically or join with a secondary vein originating from the midvein to form a marginal loop. Outer lateral primary veins (if present) are thinner than inner primaries and usually terminate at or near the margin in the lower third of the lamina. Lateral primaries produce secondary veins only abmedially. Secondaries from the upper part of the midvein and the outer secondary veins from the lateral primaries are branching to form angular brochidodromous loops of finer veins within the margin. Fine venation details are consistent with genus diagnosis.

\section{DISCUSSION}

Leaves of Paliurus colombii are elliptical, with margin varying from entire (Pl. 1, fig. 2) to undulate (Pl. 1, fig. 1) or irregularly dentate (Pl. 1, figs 4, 6, 7). Venation is actinodromous, with 3-5 primary veins. Populus arctica is characterized by elliptic, broadly elliptic or transversally elliptic leaves with undulate, crenate or dentate margin and actinodromous 3-5 nervous venation.

R.W. Brown (1939) suggested that Paliurus colombii and Populus arctica are conspecific and merged them under the name Cercidiphyllum arcticum (Heer) R.W. Brown. Later Crane with coauthors (Crane et al., 1991) united these species under the name Zizyphoides flabella. Most other scientists have not considered the question of the identity of these species.

After restudying the type material in the Colomb collection we believe that leaves of Paliurus colombii and Populus arctica exhibit 

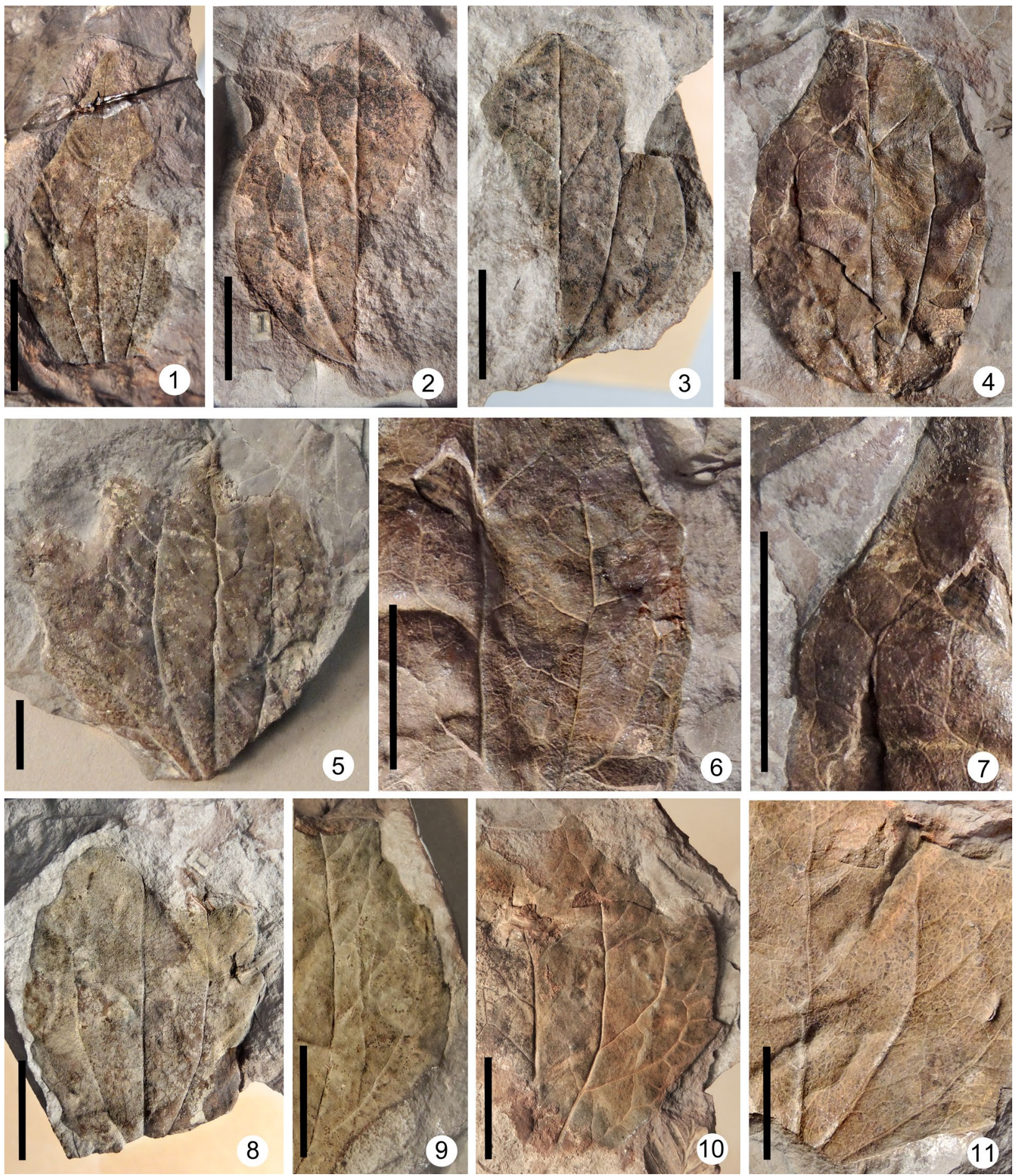

Plate 1. Leaves of Zizyphoides colombii (Heer) Seward et Conway from the Quikavsak Formation, West Greenland (specimens in figs 1-5 were described by Heer (1868) as Paliurus colombii Heer and specimens in figs 5-11 were described as Populus arctica Heer): 1. F19177/4, figured by Heer, 1868, Taf. XIX, Fig. 2; 2. F19172A, figured by Heer, 1868, Taf. XIX, Fig. 3; 3. F19172B/1, counterpart of F19172A; 4, 6, 7. F19201/2, lectotype, designated here, figured by Heer, 1868, Taf. XVII, Fig. 2 d: 4. general view; 6. Percurrent tertiary veins between midvein and inner lateral primaries, forming irregular arched connections, and loops near the margin; 7. Broadly triangular tooth with obtuse eglandular apex; 5. F19253/2, figured by Heer, 1868, Taf. XIX, Fig. 4; 8. F19172B/2, figured by Heer, 1868, Taf. V, Fig. 12; 9. F19198/1, figured by Heer, 1868, Taf. V, Fig. 2a; 10. F19195, figured by Heer, 1868, Taf. V, Fig. 5; 11. F19215/4, figured by Heer, 1868, Taf. V Fig. 7b. Scale bar is $1 \mathrm{~cm}$

a continuous range of variability and belong to one leaf population ( $\mathrm{Pls} 1-3$; Fig. 5). They have the same venation and margin features and differ slightly in the size and shape of lamina. Leaves of Paliurus colombii are smaller and narrower (length from 3 to $5.2 \mathrm{~cm}$; width from 1.3 to $4.6 \mathrm{~cm}$ ), than those of Populus arctica (length from 3.5 to $6.5 \mathrm{~cm}$; width from 2.5 to $7 \mathrm{~cm}$ ). Smaller and narrower leaves of Paliurus colombii were located most likely in 

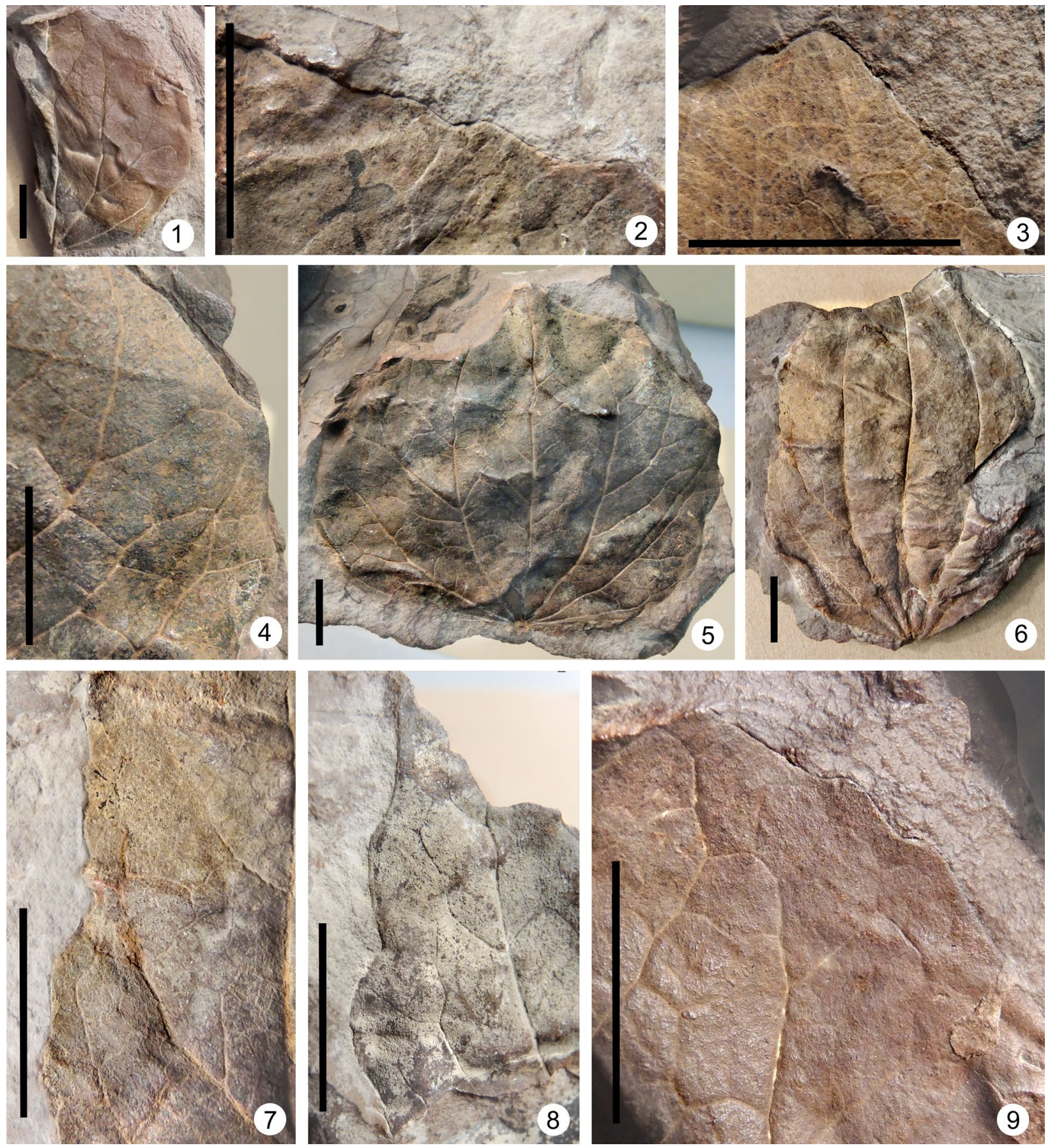

Plate 2. Leaves of Zizyphoides colombii (Heer) Seward et Conway from the Quikavsak Formation, West Greenland described by Heer (1868) under the name Populus arctica Heer: 1, 9. F19214/1, figured by Heer, 1868, Taf. V, Fig. 1a: 1. General view; 9. Irregularly dentate margin with broadly triangular teeth; 2. F19200; 3. F19214/10, quaternary venation near the margin; 4, 5. F19261/1, figured by Heer, 1868, Taf. V, Fig. 3: 4. Irregularly dentate margin with broadly triangular teeth and brochidodromous loops near the margin; 5. General view; 6. F19202, figured by Heer, 1868, Taf. V, Fig. 11; 7. F19172B/2, loops near the margin and irregular teeth; 8. F19201172B/2, figured by Heer, 1868, Taf. V, Fig. 12, crenate and triangular broad teeth with triangular and rounded broad sinuses, lower tooth is glandular. Scale bar is $1 \mathrm{~cm}$

the upper parts of the shoots, while the larger and wider leaves of Populus arctica are normally developed leaves in the middle of the shoots. Such variability is observed in most modern woody dicotyledons. We consider that species Paliurus colombii and Populus arctica are conspecific and merge them under the name Zizyphoides colombii (Heer) Seward et Conway.
Leaves of Hedera macclurii are indistinguishable from those of Populus arctica in shape, margin structure and variability (Pl. 3, fig. 3, 4). Leaves of Hakea? arctica are elliptic, entire-margined (Pl. 3, figs 1, 2) and very similar with leaves of Paliurus colombii in size, margin structure and venation. The leaf described as Populus zaddachi (Heer, 1868: 

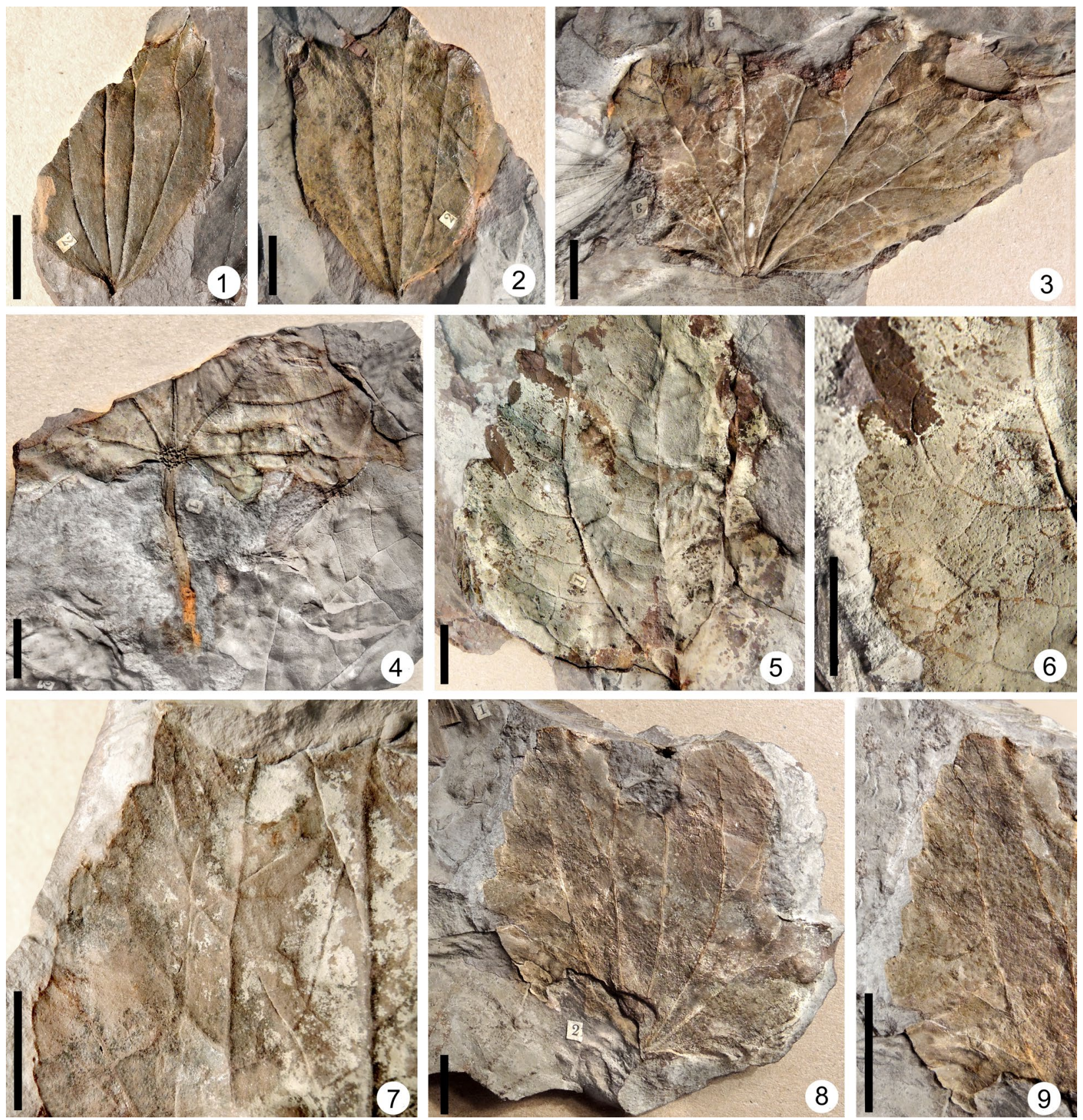

Plate 3. Leaves of Zizyphoides colombii (Heer) Seward et Conway from the Quikavsak Formation, West Greenland (specimens of Fig. 1, 2 were described by Heer (1868) as Hakea? arctica Heer, specimens of Fig. 3, 4 were described as Hedera macclurii Heer, specimen 5 was attributed as Populus zaddachii Heer, and specimens 7-9 were described as Populus arctica Heer): 1. F19294B/2; 2. F19294C/2; 3. F19201/3; 4. F19174; 5, 6. F19263, figured by Heer, 1868, Taf. VI, Fig. 3; 6. crenate teeth with central vein; 7. F19198B, irregularly crenate margin; 8. F19237/2 [1]; 9. F19237/2 [1], irregularly crenate margin. Scale bar is $1 \mathrm{~cm}$

Taf. VI, Fig. 3) is rather large (about $7 \mathrm{~cm}$ long), widely elliptic, with small irregular teeth, typical for Zizyphoides colombii (Pl. 3, figs 5, 6).

The question of the identity of Zizyphoides colombii and $Z$. flabella is not easy. These species differ only slightly in the shape of leaves and in the margin structure. The species Zizyphoides flabella (basionym Populus flabella Newberry) was described based on one widely elliptical leaf with slightly undulate margin from the Paleocene-Eocene Puget
Group, Washington (Newberry, 1863; 1898). Other specimens from the type locality are unknown and although Jenkinsella fruits occur there, we are not aware of co-occurring Nordenskioeldia fruits. Occurrences of Z flabella in other Paleocene localities of North America are abundant at various sites in Montana, Wyoming and North Dakota associated with Nordenskioeldia (Crane et al., 1991; Manchester, 2014) and they are also represented mainly by morphotypes with an entire, slightly 


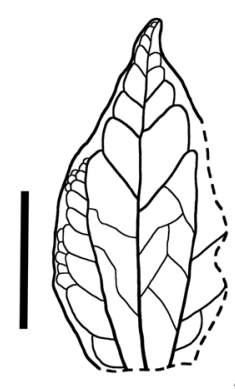

a

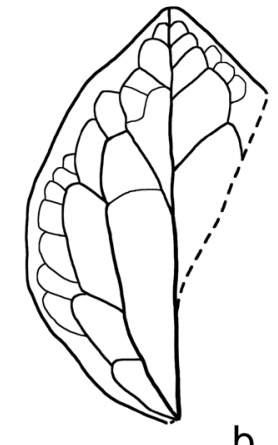

b

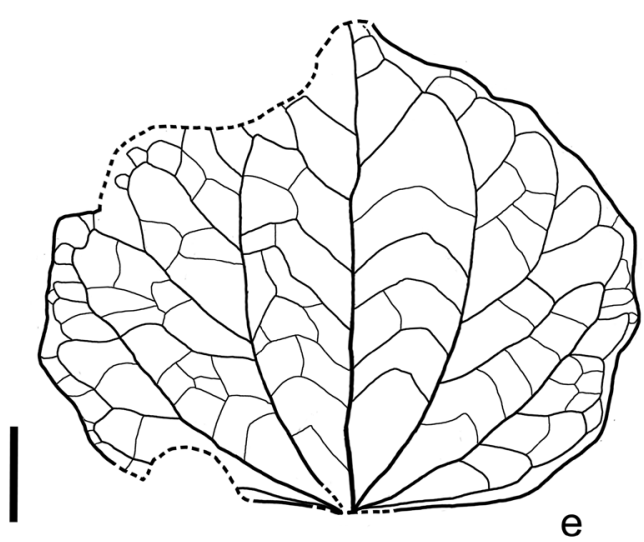

e

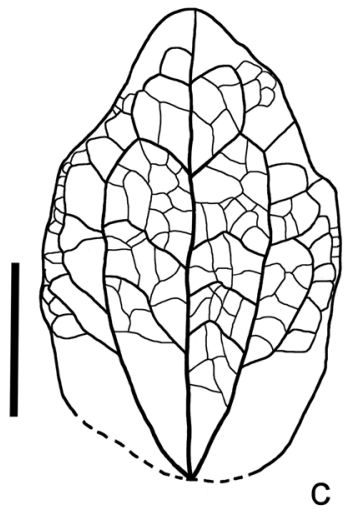

C

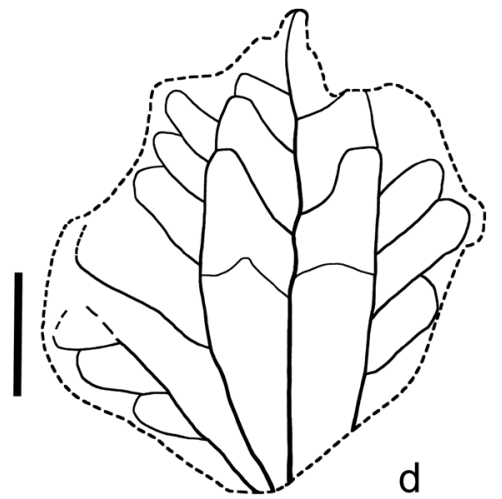

d

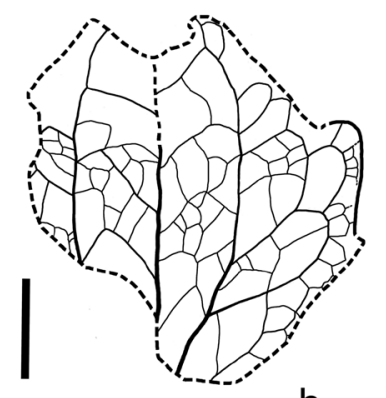

$\mathrm{h}$
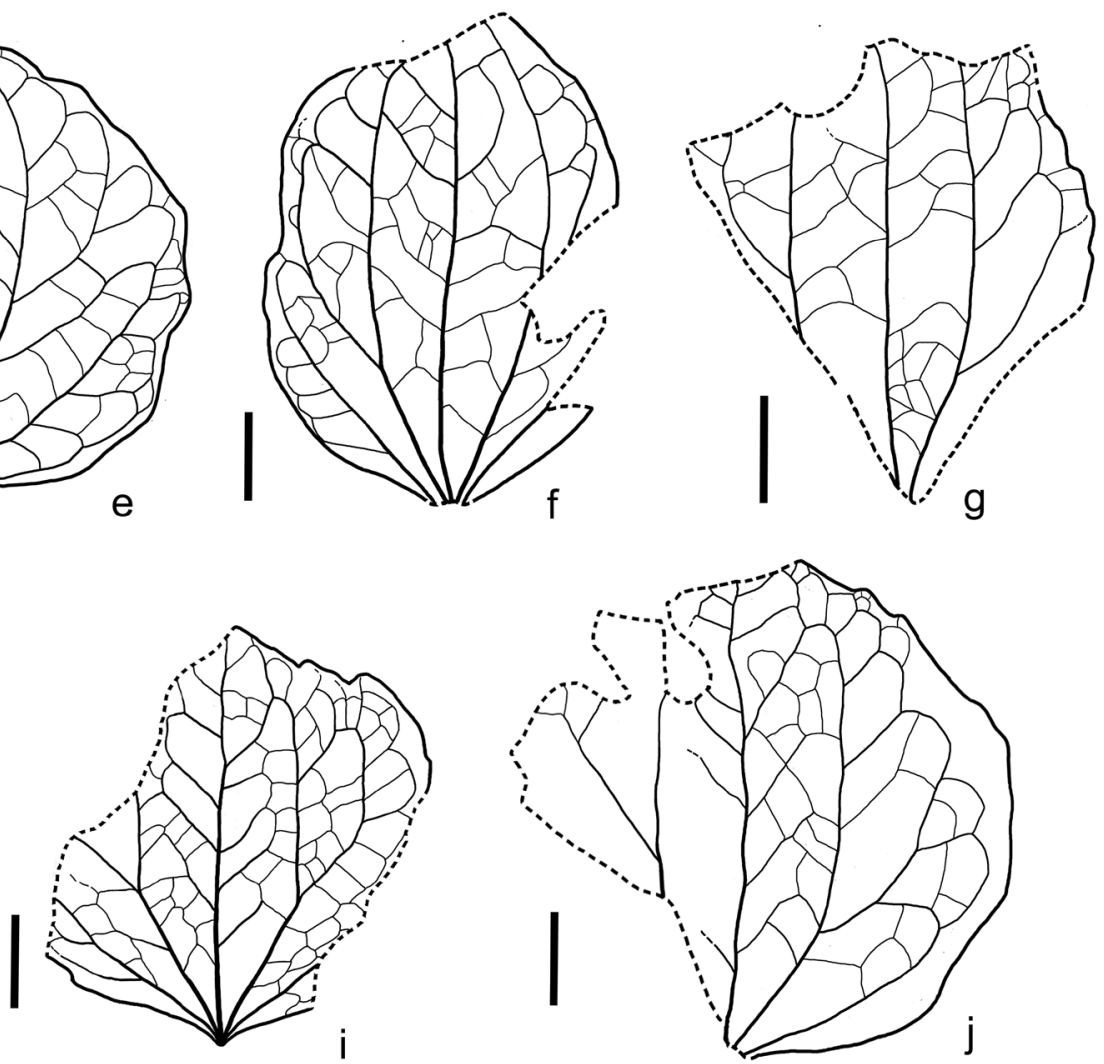

Fig. 5. Drawings of Zizyphoides colombii (Heer) Seward et Conway from the Quikavsak Formation, West Greenland (specimens A-D were described by Heer (1868) as Paliurus colombii Heer and specimen E - as Populus arctica H: a. F19177/4, figured Heer, 1868, Taf. XIX, Fig. 2; b. F19172A, figured by Heer, 1868, Taf. XIX, Fig. 3; c. F19201/2, lectotype of Zizyphoides colombii, designated here, figured by Heer, 1868, Taf. XVII, Fig. 2d; d. F19253/2, figured by Heer, 1868, Taf. XIX, Fig. 4; e. F19661/1, figured by Heer, 1868, Taf. V, Fig. 3; f. F19202, figured by Heer, 1868, Taf. V, Fig. 11; g. F19198/1, figured by Heer, 1868, Taf. V, Fig. 2a; h. F19195, figured by Heer, 1868, Taf. V, Fig. 5; i. drawing of Populus arctica lectotype, figured by Heer, 1868, Taf. V, Fig. 8, storage location is unknown; j. F19215/1, figured by Heer, 1868, Taf. V, Fig. 1a. Scale bar is $1 \mathrm{~cm}$

undulate, crenate or scalloped margin (Wolfe, 1966; Hickey, 1977).

Morphotypes with an entire or wavy margin are also characteristic of Zizyphoides colombii leaves from Greenland. However, typical leaves have a finely toothed margin with crenate or dentate teeth, each with distinct central vein. Such morphotypes have not yet been detected for the North American representatives of $Z$. flabella, although individual teeth may have a similar structure. On the other hand, obovate morphotypes with a scalloped or crenate margin, common for Z. flabella, were not found in Zizyphoides colombii. Whether it is possible to consider the finely toothed margin and differences in shape as diagnostic features for distinguishing between the two species or or they are the result of intraspecific variability, is not completely clear. To resolve this issue, it is necessary to analyze more extensive samples from both leaf populations and especially from type locality of $Z$. flabella. 
Miocene Zizyphoides auriculata leaves differ from Paleocene $Z$. flabellum and Z. colombii in having generally more prominent dentations along the margin and a broader divergence of the lateral primary veins (Manchester et al., 1991).

As mentioned above, Populus arctica was proposed as basionym for three other combinations: Cercidiphyllum arcticum (Heer) R.W. Brown (1939), Trochodendroides arctica (Heer) Berry (1926) and Cocculus arctica (Heer) Iljinskaja (1972). Two first authors, Brown and Berry, used their combinations mostly for Cercidiphyllum-like leaves, although among figured specimens there are also leaves, similar in morphology to the leaves of Zizyphoides. Brown noted co-occurrence of Cercidiphyllum arcticum leaves with follicular fruits, resembling those of extant Cercidiphyllum. However, these infructescences differ from the infructescences of Cercidiphyllum by their racemose organization and some other characters. Therefore, many paleobotanists preferred to use the formal generic name Trochodendroides for Cercidiphyllum-like leaves for different morphotypes from the Late Cretaceous and Paleogene (Bell, 1949; Kryshtofovich and Baikovskaya, 1966; Krassilov, 1976; Budantsev, 1983; Budantsev and Mokhov, 1986; Golovneva, 1994).

Wolfe (1966) was the first to recognize Zizyphoides-like leaves as a separate entity among the diversity of trochodendrophylls. $\mathrm{He}$ attributed them to the modern genus Cocculus and combined all the previously described fossils of similar morphology under the name Cocculus flabella (Newberry) Wolfe, including Populus arctica. The combination Cocculus arctica was created by Iljinskaja (1972). Following Wolfe (1966), Iljinskaja attributed to the genus Cocculus only leaves with entire, wavy or irregularly toothed margin. However, she included several fossil species in this genus and considered Cocculus arctica and C. flabella to be different species.

\section{CONCLUSIONS}

After restudying the type material in the Colomb collection we found that leaves described by Heer (1868) under the names Paliurus colombii, Populus arctica, Hakea? arctica, and Hedera macclurii exhibit a continuous range of variability and belong to one population. These species are conspecific and were united under the name Zizyphoides colombii.

This species is the type species of the genus Zizyphoides Seward et Conway. We have designated a lectotype of Zizyphoides colombii and provided an emended diagnosis of this species and of the genus Zizyphoides.

\section{ACKNOWLEDGEMENTS}

We are grateful to Nigel Monaghan and Matthew Parker from the National Museum of Ireland and anonymous reviewers. This study was supported by the Russian Foundation for Basic Research (Project No 19-34-90170) and carried out within the framework of the institutional research project (AAAAA19-119030190018-1) of the BIN RAS (St. Petersburg, Russia).

\section{REFERENCES}

Baikovskaya, T.N., 1956. Verhnemelovye flory Severnoj Azii. Acta of the Komarov Botanical Institute, ser. 8 2, 49-181 (in Russian).

Bell, W.A., 1949. Uppermost Cretaceous and Paleocene floras of western Alberta. Geological Survey of Canada, Bulletin 13, 1-231. https://doi. org/10.4095/101514

Berry, E.W., 1926. Tertiary floras from British Columbia. Geological Survey of Canada, Museum Bulletin 42, 91-116. https://doi.org/10.4095/105011

Brown, R.W., 1939. Fossil leaves, fruits and seeds of Cercidiphyllum. Journal of Paleontology 13, 485-499.

Budantsev, L.Yu., 1968. The Late Cretaceous flora of the Vilyui depression. Botanicheskii Zhurnal 53(1), $3-16$.

Budantsev, L.Yu., 1983. History of the Arctic flora of the Early Cenophytic epoch. Leningrad. Nauka.

Budantsev, L.Yu., Mokhov, E.P., 1986. Morfologicheskaya izmenchivost' list'ev i taksonomiya roda Trochodendroides $\mathrm{v}$ ranneeocenovoj flore Zapadnoj Kamchatki. In: Budantsev, L.Yu. (ed.), Problem of palaeobotany. Nauka, Leningrad, pp. 19-27 (in Russian).

Crane, P.R., 1984. A re-evaluation of Cercidiphyllumlike plant fossils from the British early Tertiary. Botanical Journal of the Linnean Society 89, 199-230. https://doi.org/10.1111/j.1095-8339.1984. tb02196.x

Crane, P.R., Manchester, S.R., Dilcher, D.L., 1991. Reproductive and vegetative structure of Nordenskioldia (Trochodendraceae), a vesselless dicotyledon from the Early Tertiary of the Northern hemisphere. American Journal of Botany 78, 1311-1344. https://doi.org/10.1002/j.1537-2197.1991.tb12599.x

Crane, P.R., Stockey, R.A., 1985. Growth and reproductive biology of Joffrea speirsii gen. et sp. nov., 
a Cercidiphyllum-like plant from the Late Paleocene of Alberta, Canada. Canadian Journal of Botany 63, 340-64. https://doi.org/10.1139/b85-041

Crane, P.R., Stockey, R.A., 1986. Morphology and development of pistillate inflorescences in extant and fossil Cercidiphyllaceae. Annals of the Missouri Botanical Garden 73, 382-393. https://doi. org/10.2307/2399118

Dam, G., Pedersen, G.K., Sønderholm, M., Midtgaard, H.H., Larsen, L.M., Nøhr-Hansen, H., Pedersen, A.K., 2009. Lithostratigraphy of the CretaceousPaleocene Nuussuaq Group, Nuussuaq Basin, West Greenland. Geologic survey of Denmark and Greenland Bulletin 19, 1-171. https://doi. org/10.34194/geusb.v19.4886

Ellis, B., Daly, D., Hickey, L.J., Johnson, K., Mitchell, J., Wilf, P., Wing, S., 2009. Manual of leaf architecture. New York. Cornell Univ. Press.

Golovneva, L.B., 1994. Maastrichtian-Danian floras of the Koryak Upland. Proceedings of the Komarov Botanical Institute 13, 1-147.

Golovneva, L.B., Alekseev, P.I., 2017. Taxonomy and morphological diversity of infructescences Jenkinsella co-occurred with Trochodendroides leaves in the Cretaceous and Paleogene. Palaeobotany 8, 92-121. https://doi.org/10.31111/palaeobotany/2017.8.92

Heer, O., 1959. Flora tertiaria Helvetiae: Die tertiäre Flora der Schweiz, Band 3. Winterthur. J. Würster and comp.

Heer, O., 1866. Uber den versteinerten Wald von Atanekerdluk in Nordgronland. Vierteljahrsschrift der Naturforschenden Gesellschaft in Zürich 11, 259-295.

Heer, O., 1868. Flora fossilis arctica. Die fossile Flora der Polarlander, Vol. 1. Zürich. Druck und Verlag von Friedrich Schulthess, pp. 1-192. https://doi. org/10.5962/bhl.title.52346

Herman, A.B., 2011. Albian-Paleocene flora of the North Pacific. Transactions of the Geological Institute 592, 1-279.

Herman, A.B., 2013. Albian-Paleocene flora of the North Pacific: systematic composition, palaeofloristics and phytostratigraphy. Stratigraphy and Geological Correlation 21(7), 689-747. https://doi. org/10.1134/S0869593813070034

Herman, A.B., Lebedev, E.L., 1991. Cretaceous stratigraphy and flora of Northwestern Kamchatka. Transactions of the Geological Institute 468, 1-189.

Hickey, L.J., 1977. Stratigraphy and paleobotany of the Golden Valley Formation (Early Tertiary) of western North Dakota. Geological Society of America Memoir 150, 1-181.

Hollick, A., 1936. The Tertiary floras of Alaska. U.S. Geological Survey Professional Paper 182, 1-185.

Iljinskaja, I.A., 1972. Correction of the volume of genus Trochodendroides and new fossil species Cocculus. Botanicheskii Zhurnal 57(1), 17-30.
Koch, B.E., 1959. Contribution to the stratigraphy of the non-marine Tertiary deposits on the south coast of the Nûgssuaq peninsula, northwest Greenland with remarks on the fossil flora. Bulletin Grønlands Geologiske Undersøgelse 22, 1-100.

Koch, B.E., 1963. Fossil plants from the Lower Paleocene of the Agatdalen (Angmartussut) Area, Central Nugssuaq Peninsula, North-West Greenland. Meddelelser om Grønland 172, 1-120.

Krassilov, V.A., 1976. Cagayanskaya flora Amurskoj oblasti. Moscow. Nauka (in Russian).

Kryshtofovich, A.N., Baikovskaya, T.N., 1966. Verhnemelovaya flora Cagayana v Amurskoj oblasti. In: Baranov, P.A., Takhtajian, L.A., Baikovskaya, T.N. (eds), Selections of A.N. Kryshtofovich. Nauka, Leningrad, pp. 184-320 (in Russian).

Manchester, S.R., 2014. Revisions to Roland Brown's North American Paleocene flora. Acta Musei Nationalis Pragae, Ser. B - Historia Naturalis 70(3-4): 153-210. https://doi.org/10.14446/ AMNP.2014.153

Manchester, S.R., Crane P.R., Dilcher, D.L., 1991. Nordenskioldia and Trochodendron (Trochodendraceae) from the Miocene of northwestern North America. Botanical Gazette 152(3), 357-368. https://doi.org/10.1086/337898

Manchester, S.R., Chen, Z., Geng, B., Tao, J., 2005. Middle Eocene flora of Huadian, Jilin Province, Northeastern China. Acta Palaeobotanica 45(1), $3-26$.

Newberry, J.S., 1863. Descriptions of fossil plants collected by Mr. George Gibbs. Boston Natural History Journal 7, 506-524.

Newberry, J.S., 1898. The later extinct floras of North America. Monographs of the United States Geological Survey 35, 1-295.

Nordenskiöld, A.E., 1871. Redogörelse för en expedition till Grönland år 1870. Öfversigt Kungliga Vetenskaps-Akademiens Förhand-lingar 27, 973-1082.

Philippova, G.G., 2010. Cretaceous stratigraphy and floral assemblages of the Northern Pekulney Ranges (Chukotka). Magadan. North-East Interdisciplinary Scientific Research Institute NANA Shilo, Far East Branch, Russian Academy of Sciences (in Russian).

Philippova, G.G., Abramova, L.N., 1993. Pozdnemelovaya flora Severo-Vostoka Rossii. Moscow. Nedra (in Russian).

Seward, A.C., Conway, V., 1935. Fossil plants from Kingitok and Kagdlunguak, West Greenland. Meddelelser om Grønland 93, 1-41.

Tanai, T., 1961. Neogene floral change in Japan. Journal of the Faculty of Science, Hokkaido University. Series 4, Geology and mineralogy 11(2), 119-398.

Wolfe, J.A., 1966. Tertiary plants from the Cook inlet region, Alaska. U.S. Geological Survey Professional Paper 398B, 1-32. https://doi.org/10.3133/pp398B 